\title{
Microbial quality of drinking water from groundtanks and tankers at source and point-of-use in eThekwini Municipality, South Africa, and its relationship to health outcomes
}

\author{
U Singh ${ }^{1}$, R Lutchmanariyan ${ }^{2}$, J Wright ${ }^{3}$, S Knight ${ }^{3}$, S Jackson ${ }^{4}, \mathrm{~J} \mathrm{Langmark}^{5}$, D Vosloo ${ }^{6}$ and N Rodda ${ }^{1 *}$ \\ ${ }^{1} S$ chool of Life Sciences, University of KwaZulu-Natal, Westville, Private Bag X54001, Durban, 4000, South Africa \\ ${ }^{2}$ Environmental Health Department, eThekwini Municipality, PO Box 2443, Durban, 4000, South Africa \\ ${ }^{3}$ Nelson R. Mandela School of Medicine, University of KwaZulu-Natal, Private Bag 7, Congella, 4013, South Africa \\ ${ }^{4}$ Scientific Services, eThekwini Water and Sanitation, eThekwini Municipality, PO Box 1038, Durban, 4000, South Africa \\ ${ }^{5}$ Swedish Institute of Infectious Disease Control, Stockholm, SMI, SE 171 82, Solna, Sweden
}

\begin{abstract}
Drinking water quality was investigated at source and corresponding point-of-use in 2 peri-urban areas receiving drinking water either by communal water tanker or by delivery directly from the distribution system to household-based groundtanks with taps. Water quality variables measured were heterotrophic bacteria, total coliforms, E. coli, conductivity, turbidity, $\mathrm{pH}$, and total and residual chlorine. Water quality data were analysed together with an existing epidemiological database to investigate links between microbial quality of drinking water, household demographics, health outcomes, socio-economic status, hygiene and sanitation practices. Groundtank households had better quality drinking water than households using storage containers filled from communal tankers. Uncovered storage containers had the poorest microbial water quality among all storage containers. All stored water did not meet drinking water standards, although mains water did. Households with children under 5 years and using open-topped containers had the poorest water quality overall. Households with groundtanks had the best water quality at point-of-use, but did not have the lowest occurrence of health effects. Although groundtanks were supplied together with urine diversion (UD) toilets and hygiene education, groundtank households showed overall poorer hygiene practices than tanker-supplied households, and some groundtank households with UD toilets preferred to continue using open defecation. Households that practised open defecation had higher levels of $E$. coli in their drinking water and higher rates of adverse health outcomes. Poorer socio-economic standing and lower educational standard were associated with poorer water quality, poorer hygiene practices and higher rates of diarrhoea and vomiting.
\end{abstract}

Keywords: drinking water; point of use; water quality; water quantity; hygiene; sanitation

\section{INTRODUCTION}

South Africa has large areas that lack adequate supplies of potable water and sanitation. A lack of infrastructure, coupled with rapid population growth in rural and peri-urban areas, is a major contributing factor to this problem. Where improved drinking water has been provided to such communities, water is often stored in the home prior to use. Here, 'improved water source' is defined as at least $20 \ell$ of water per capita per day from a protected source which is piped into a yard, dwelling or standpipe and which is no further than $200 \mathrm{~m}$ away from the user's dwelling. It thus often still involves collection and storage of water prior to use. Microbial contamination of water during storage, collection and transportation is of concern since contamination may result in water that is unsafe for human consumption (Jagals et al., 1997, 2004; WHO, 2005).

The responsibility for supplying the city of Durban (South Africa) and its surrounding areas with drinking water rests with eThekwini Municipality. Since rural and peri-urban areas in Durban often lie outside the waterborne sewerage network, the Municipality initiated a programme to provide sanitation

To whom all correspondence should be addressed.

Teli +27 31 260-3015; fax +27 31 260-2029;

e-mail: roddan@ukzn.ac.za

Received 3 October 2012; accepted in revised form 23 September 2013. to these areas via urine diversion (UD) toilets, coupled with the provision of drinking water by groundtanks, along with health and hygiene education. Groundtanks are $200 \ell$ closed containers which are filled from mains once daily. The tanks are fitted with a tap for dispensing water. In settlements which have not yet been serviced under this programme, sanitation provision is by pit latrines or open defecation is practised. Treated drinking water is provided to such areas via standpipes or mobile water tankers (KwaZulu-Natal Municipalities, 2008).

Water provision via standpipes and mobile water tankers requires users to collect, transport and store water prior to use, whilst groundtanks themselves serve as a storage container. In the case of standpipes and mobile water tankers, water is collected, transported to and stored in households in either open-top or closed-top portable storage containers. Numerous studies have demonstrated the deterioration in microbiological quality of drinking water as it moves from source to point-of-use (Moyo et al., 2004; Trevett et al., 2005; Gundry et al., 2006; Onabulo et al., 2011), leaving the water unsafe for human consumption (Momba et al., 2003; Moyo et al., 2004; Trevett et al., 2005; Gundry et al., 2006). Factors thought to contribute to deterioration in water quality include poor hygiene and sanitation practices; the use of contaminated transport and storage containers; insertion of contaminated hands and utensils into water; contact of water with particulate matter, animals and insects as a result of 
openings in containers; and a poor environment surrounding the water source (Jagals et al., 1997; Roberts et al., 2001; Momba et al., 2003; Trevett et al., 2004, 2005; Onabulo et al., 2011). Water stored in open-top containers is more prone to faecal contamination than water stored in closed-top containers and may contain faecal pathogens that could cause illness such as diarrhoea (Jagals et al., 1997; Roberts et al., 2001). Faecal contamination of water results from users dipping faecallycontaminated utensils and hands into storage containers (Swedlow et al., 1997; Islam, 2001; Trevett, 2003, Trevett et al., 2004).

Deterioration of point-of-use drinking water quality has also in the past been associated with the age of household members (Yeager, 1991; Trevett et al., 2004). Stored water in households including children aged 5 years or younger has been shown to have higher counts of faecal pathogens and other microbes than that in households with all other age groups (Roberts et al., 2001). This has been shown to be especially prevalent in areas where open defecation is practised, since children usually have direct access to these areas and they would contaminate drinking water by inserting contaminated hands or utensils into water storage vessels when removing water for use (Roberts et al., 2001; Trevett, 2003; Trevett et al., 2005).

Poor microbial quality of drinking water has been linked to various health conditions, most typically manifesting as diarrhoea, vomiting and gastroenteritis (Chanlett, 1992; American Society for Microbiology, 2002; Yang et al., 2011), particularly in the under-5 age group. However, the link between human health and microbial drinking water quality in isolation has been contested. Whilst some studies have shown that good microbial quality of drinking water is related to a reduction in health outcomes (Payment et al., 1991, 1993), other studies suggest that a reduction in health outcomes is more likely to be achieved through the provision of good quality and quantity of water in conjunction with proper hygiene practices and good sanitation (Esrey et al., 1991; Payment et al., 1993; Peter, 2010; Hubbard et al., 2011).

The aim of the present study was to evaluate the microbiological quality of drinking water from groundtanks and community tankers and its relationship to health outcomes in light of water quality, demographic distribution and sanitation and hygiene education provision.

\section{EXPERIMENTAL}

\section{Study site}

Two peri-urban areas in Durban, South Africa, were used as study sites, namely Sawpitts and Mtamuntengayo. Sawpitts and Mtamuntengayo, southwest of Durban, are approximately $35 \mathrm{~km}$ from the Durban city centre.

Water is supplied to dwellers in Sawpitts via semi-pressure groundtanks whilst dwellers in Mtamuntengayo receive water via mobile tankers. This study compared the microbial and physico-chemical properties of drinking water at the source to those at the corresponding points-of-use (Fig. 1). The source of water in this instance was defined as the origin or starting point from which improved (treated) water supplied to a specific water delivery system originated. The point-of-use was defined as the point from which consumers used water directly.

In the case of semi-pressure groundtanks, the tanks in the yards of individual households were considered to be representative of point-of-use water, since they served as both a storage vessel and a dispensing vessel. For this form of water delivery, taps at the eThekwini Water and Sanitation laboratory were taken as representative of source water since groundtanks were supplied with water from the same municipal distribution system (Fig. 1). Tankers were considered as a source of treated municipal water because it was a communal system and required that water be collected from the tanker, transported to the household and stored until used. The points-of-use in this case were the storage vessels from which water was used, i.e., either open-top or closed top containers (Fig. 1).

\section{Household selection}

The current study combined results of an earlier epidemiological study that included information on socio-economic status, health outcomes and sanitation practices of households with data on microbial quality of drinking water at selected households from the epidemiological study to investigate the relationship between drinking water quality, health, hygiene and sanitation (Lutchminarayan, 2007). A sample population of 72 households was selected as a subset from the database consisting of 1350 households used in the epidemiological study. Households for the current study were selected based on the type of water delivery system (groundtanks or tankers), household demographics (households including children aged $0-5$ years, households including children aged $5-18$ years and households comprising adults only), and type of storage containers used to store drinking water (open-top or closed-top storage containers). Epidemiological information on household members was collected via questionnaire surveys. Three surveys were used:

Household questionnaires to gather general information on the socio-economic status of household members, the type of water and sanitation facilities, health and hygiene practices and education levels in households. Details on occupants of the 


\section{TABLE 1}

Household selection criteria, based on demographic composition of households in Sawpitts and Mtamuntengayo which store drinking water in groundtanks or in open-top or closed-top storage containers, respectively. The water source and corresponding point-of-use are also given.

\begin{tabular}{|l|l|l|l|}
\hline Area & Household demographic group & Water source & Point-of-use samples \\
\hline Sawpitts & $\begin{array}{l}\text { - Households with children aged 0-5 years } \\
\text { - Households with children aged between 5 and 18 years } \\
\text { - Households comprising adults only (>18 years) }\end{array}$ & $\begin{array}{l}\text { eThekwini } \\
\text { Municipality } \\
\text { taps }\end{array}$ & $\begin{array}{l}\text { Water stored in } \\
\text { groundtanks for } \\
\text { up to 4h }\end{array}$ \\
\hline Mtamuntengayo & $\begin{array}{l}\text { Households with children aged 0-5 years } \\
- \text { Households with children aged between 5 and 18 years } \\
- \text { Households comprising adults only (>18 years) }\end{array}$ & $\begin{array}{l}\text { Community } \\
\text { tankers }\end{array}$ & $\begin{array}{l}\text { Water stored } \\
\text { in open-top } \\
\text { containers }\end{array}$ \\
\hline Mtamuntengayo & $\begin{array}{l}\text { Households with children aged 0-5 years } \\
- \text { Households with children aged between 5 and 18 years } \\
\text { - Households comprising adults only (>18 years) }\end{array}$ & $\begin{array}{l}\text { Community } \\
\text { tankers }\end{array}$ & $\begin{array}{l}\text { Water stored } \\
\text { in closed-top } \\
\text { containers }\end{array}$ \\
\hline
\end{tabular}

household, number of members in households, age distributions, and possession checklists (to indicate socio-economic status and levels of education) were also recorded.

Health outcomes questionnaires to determine the rates of diarrhoea (defined as the release of 3 or more loose or watery stools in a 24-h period (Baqui et al., 1991)) and vomiting (defined as the ejection of part of or all of the contents of the stomach through the mouth, usually in a series of involuntary spasmic movements (Guyton and Hall, 2006)), and the duration of such health outcomes in household members participating in the study. Whilst the incidence of diarrhoea was recorded, the aetiology of diarrhoea was not investigated from a clinical perspective.

Observational questionnaires to determine if information given in the household questionnaire corresponded to what was observed in the surroundings. This served as a method of confirmation of the preceding two questionnaires. All observational questionnaires were completed by trained members of the research team in personal interviews.

The microbial study was not conducted at the same time as the epidemiological study due to resource constraints. Thus water quality as measured in this study was considered to be indicative of drinking water quality prevalent in the two areas sampled. The water quality study was 'blind' in terms of the epidemiological study outcomes.

\section{Water sampling}

Drinking water was sampled once a day for a total of 10 days over a 2-week period from the point-of-use and source of each household, for both microbial analyses and physico-chemical analyses. Before sampling, the taps on groundtanks and community tankers were wiped down with $90 \%$ ethanol and flushed for 1-2 min. Water was collected directly from taps into sterilised $200 \mathrm{~m} \ell$ bottles containing 3-4 drops of sodium thiosulphate. A second sample of drinking water from groundtanks and tanker taps was collected in $100 \mathrm{~m} \ell$ bottles and was used to measure physico-chemical properties. Water from open-top and closed-top storage containers (supplied by tankers) was collected by pouring water directly into sample bottles according to the analyses to be performed.

All water samples were analysed at the eThekwini Water and Sanitation laboratory. Microbial analyses included E. coli, total coliforms and heterotrophic organisms. Physico-chemical analyses included $\mathrm{pH}$, water temperature, turbidity, conductivity, total chlorine and residual chlorine. Analytical methods are presented below.

\section{Enumeration of $E$. coli and total coliforms}

The membrane filtration technique was used to detect $E$. coli and total coliform bacteria (Standard Methods, 2005; as applied in eThekwini Municipality, 2004a). Briefly, $100 \mathrm{~m} \ell$ of each sample was filtered through a sterile membrane filter with a $0.45 \mu \mathrm{m}$ pore size. Membrane filters were placed on Chromocult ${ }^{\circ}$ coliform agar (Merck) and incubated at $37^{\circ} \mathrm{C}$ for $12 \mathrm{~h}$. This was done in triplicate for all samples. Following incubation, colonies on the surface of the filter were counted. Blue colonies represented E. coli colonies, and pink colonies represented total coliform colonies. Colony numbers were reported as colony forming units (CFU) per $100 \mathrm{~m} \ell$.

\section{Enumeration of heterotrophic organisms}

The standard pour plate method was used to enumerate heterotrophic organisms (eThekwini Municipality, 2004b). Heterotrophic plate count agar (Merck) was poured into a $90 \mathrm{~mm}$ sterile Petri dish, and was inoculated with $1 \mathrm{~m} \ell$ of water sample. Plates were incubated at $37^{\circ} \mathrm{C}$ for $24 \mathrm{~h}$. Following incubation, colonies were enumerated and reported as $\mathrm{CFU} / \mathrm{m} \ell$.

\section{Statistical analysis}

Statistical analyses were conducted in SPSS version 15 except where indicated differently. Microbial data waere tested for normality of distribution using the Kolmogrov-Smirnov test. Microbial data did not show Gaussian distribution. Logtransformation of microbial data did not yield a normal distribution due to the extreme variability in microbial counts. Data were therefore ranked and analysed non-parametrically for difference of means, using the Kruskall-Wallis test.

All physico-chemical data were tested for normality of distribution using the Kolmogrov-Smirnov test. Data were found to be normally distributed and significant differences between means was tested with a one-way analysis of variance (ANOVA) coupled with least significant difference (LSD) post-hoc testing.

Water quality and epidemiological data sets were merged and statistical analyses were performed in order to identify significant relationships between (i) the independent variables, i.e. water quality, socio-economic status, sanitation and hygiene practices, water source and storage, and (ii) the dependant variables, i.e. disease outcomes (diarrhoea and vomiting). Bivariate analysis was performed between all possible pairs of variables from independent and dependant variable groups to identify significant relationships. Factors found to be significantly 
associated with disease outcomes were then used to build multivariate models for each outcome. For all analyses, $p<0.05$ was considered as statistically significant. Bivariate analysis was performed on SPSS version 15 whilst multivariate analysis was performed using either SPSS version 15 or STATA version 10. In order to control for the effect of follow-up time and number of people in each household on the number of cases of diarrhoea in each household, this disease outcome was expressed as a rate:

Incidence Rate Ratio (IRR) $=$ [(cases of diarrhoea in household)/(number of household members $\times$ follow-up time in days) $] \times 1000$ )

Spearman's rank correlation, Mann-Whitney and KruskalWallis tests were used for bivariate analyses exploring associations between diarrhoea rate (quantitative) and other factors where these factors were (i) quantitative, (ii) categorical with 2 categories, and (iii) categorical with more than 2 categories, respectively. Factors identified as significantly associated with diarrhoea rate in bivariate analyses were further analysed using Poisson regression (by generalised linear modelling with a Poisson distribution and log link function in STATA 10), in which the dependent variable was the number of cases of diarrhoea and the exposure variable was total time (number of household members multiplied by follow-up time in days). Goodness of fit tests (through the count outcomes Poisson regression function in STATA 10) and likelihood ratio chisquared tests were performed to test the fit and significance of models.

\section{RESULTS}

Results for physico-chemical measurements are given in Table 2 below. The $\mathrm{pH}$ in all groups was within limits recommended by DWAF and WHO guidelines (DWAF, 2002; WHO,
2005). Residual chlorine levels in point-of-use water from tankers and from groundtank water from Sawpitts were below levels recommended in DWAF and WHO guidelines.

Total chlorine levels in all groups were below the recommended levels of 2 to $2.5 \mathrm{mg} / \ell$. Turbidity in all groups except source water for community tankers was within the recommended levels of 1-5 NTU. Conductivity in all sample groups was within the guideline levels of $100 \mathrm{mS} / \mathrm{m}$ (DWAF, 2002; WHO, 2005).

High turbidity, in this instance, was associated with low residual and total chlorine levels and lower conductivity levels. The highest turbidity was observed in communal water sources (community tankers) and the associated point-of-use water, whether stored in open-top or closed-top containers (Table 2).

The standard deviation and number of data points used for all physico-chemical parameters is also given in Table 2 . The standard deviation for $\mathrm{pH}$, residual and total chlorine in all sample groups was below 1 . This indicated low dispersion of data. Turbidity in water samples from all sample groups except tanker point-of-use water had a standard deviation $<1$. The higher standard deviation as observed for tanker households represents the high level of dispersion of this data. It implies that a few households may have had very high turbidity values whilst a larger number of these households may have had low turbidity values.

Source water for groundtanks complied with DWAF and WHO guidelines (DWAF, 2002; WHO, 2005) for heterotrophic organisms, total coliforms and E. coli. By contrast, source water at tankers did not comply with these guidelines, indicating that households supplied by water tankers received water of poor quality prior to any further deterioration during storage (Fig. 2)

Households using groundtanks had significantly better water quality at point-of-use than did households using open-top or closed-top containers, as is indicated by the number of E. coli, total coliforms and heterotrophic plate count bacteria (Fig. 3). This was statistically significant when compared

\begin{tabular}{|c|c|c|c|c|c|c|}
\hline \multicolumn{7}{|c|}{$\begin{array}{l}\text { TABLE } 2 \\
\text { Average } \mathrm{pH} \text {, residual } \mathrm{Cl}(\mathrm{mg} / \ell) \text {, total } \mathrm{Cl}(\mathrm{mg} / \mathrm{\ell}) \text {, turbidity }(\mathrm{NTU}) \text { and conductivity }(\mathrm{mS} / \mathrm{m}) \text { for all source and } \\
\text { point-of-use water samples. } \mathrm{n} \text { represents the sample size, SD represents the standard deviation }\end{array}$} \\
\hline Sample groups & & $\mathrm{pH}$ & $\begin{array}{c}\text { Residual } \\
\text { chlorine }(\mathrm{mg} / \mathrm{l})\end{array}$ & $\begin{array}{c}\text { Total chlorine } \\
(\mathrm{mg} / \mathrm{l})\end{array}$ & $\begin{array}{l}\text { Turbidity } \\
\text { (NTU) }\end{array}$ & $\begin{array}{c}\text { Conductivity } \\
(\mathrm{mS} / \mathrm{m})\end{array}$ \\
\hline \multirow{3}{*}{$\begin{array}{l}\text { Tanker source (for sam- } \\
\text { ples from closed-top } \\
\text { containers) }\end{array}$} & & 8.1 & 0.03 & 0.07 & 1.7 & 12 \\
\hline & $\mathrm{n}$ & 34 & 34 & 34 & 34 & 34 \\
\hline & SD & 0.08 & 0.04 & 0.07 & 0.22 & 0.56 \\
\hline \multirow{3}{*}{$\begin{array}{l}\text { Tanker container } \\
\text { (Closed-top) }\end{array}$} & & 8.1 & 0.07 & 0.2 & 0.78 & 13 \\
\hline & $\mathrm{n}$ & 240 & 240 & 240 & 240 & 240 \\
\hline & SD & 0.1 & 0.16 & 0.64 & 0.21 & 0.73 \\
\hline \multirow{3}{*}{$\begin{array}{l}\text { Tanker source for } \\
\text { samples from open-top } \\
\text { containers) }\end{array}$} & & 8.1 & 0.04 & 0.06 & 2.6 & 11 \\
\hline & $\mathrm{n}$ & 34 & 34 & 34 & 34 & 34 \\
\hline & SD & 0.14 & 0.63 & 0.98 & 0.37 & 0.18 \\
\hline \multirow{3}{*}{$\begin{array}{l}\text { Tanker container } \\
\text { (Open-top) }\end{array}$} & & 8 & 0.07 & 0.1 & 1.9 & 12 \\
\hline & $\mathrm{n}$ & 240 & 240 & 240 & 240 & 240 \\
\hline & SD & 0.19 & 0.14 & 0.19 & 1.41 & 3.1 \\
\hline \multirow[t]{3}{*}{ Ground tank source } & & 7.56 & 0.16 & 0.57 & 0.03 & 10.24 \\
\hline & $\mathrm{n}$ & 40 & 40 & 40 & 40 & 40 \\
\hline & SD & 0.30 & 0.08 & 0.09 & 0.9 & 1.27 \\
\hline \multirow{3}{*}{$\begin{array}{l}\text { Groundtanks } \\
\text { point-of-use }\end{array}$} & & 8.08 & 0.07 & 0.1 & 0.53 & 12.41 \\
\hline & $\mathrm{n}$ & 280 & 280 & 208 & 208 & 208 \\
\hline & SD & 0.11 & 0.52 & 0.08 & 1.0 & 0.82 \\
\hline
\end{tabular}



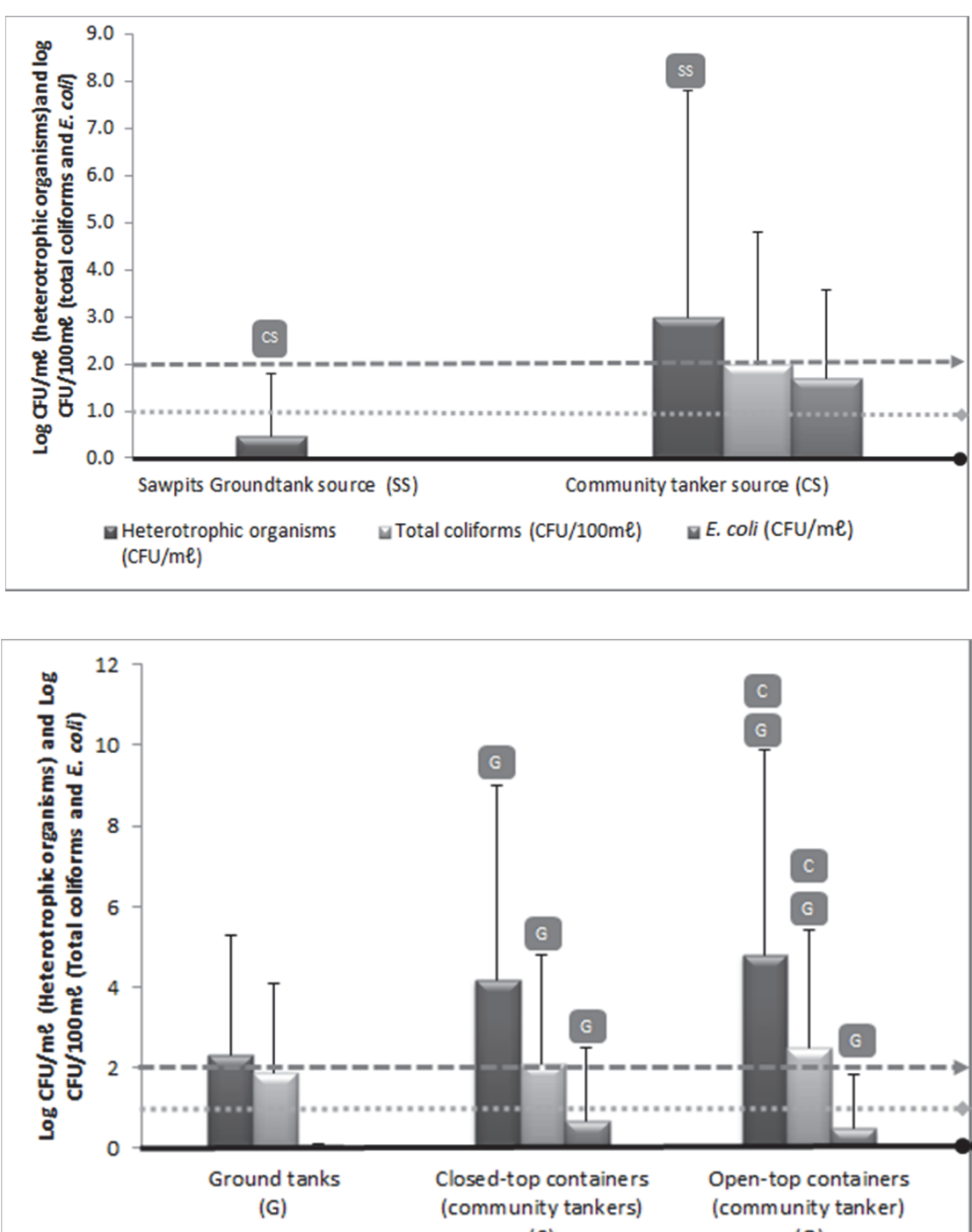

(C)
(O)
Figure 2

Log arithmetic mean microbial counts at source for households using groundtanks as a water delivery system (Sawpitts groundtanks source) and for community tanker-supplied households (Community tanker source). Error bars represent the $95^{\text {th }}$ percentile. Horizontal lines represent maximum values of heterotrophic organisms (dark grey line with arrowhead), total coliforms (grey line with diamond head) and $\mathrm{E}$. coli (black line with rounded head) counts allowed in drinking water rendered safe for human consumption by DWAF. Boxes represent significant differences in microbial counts.

\section{Figure 3}

Log arithmetic mean microbial counts at point-of-use for households using groundtanks as a water delivery and storage system and for community tanker-supplied households using closed-top and open-top containers as water storage systems. Error bars represent the $95^{\text {th }}$ percentile. Horizontal lines represent maximum values of heterotrophic organisms (dark grey line with arrowhead), total coliforms (grey line with diamond head) and E. coli (black line with rounded head) counts allowed in drinking water rendered safe for human consumption by DWAF. Boxes represent significant differences in microbial counts.

$\square$ Heterotrophic organisms (CFU/me) $\square$ Total coliforms (CFU/me) $\square E$. coli (CFU/me)

with that in open-top and closed-top containers (in all cases $p<0.0005)$. The number of $E$. coli in open-top and closed-top containers was not significantly different; however, there were more total coliforms and heterotrophic organisms in open-top containers when compared with closed-top containers (Fig. 3) and this was statistically significant $(p<0.0005$ and $p=0.001$, respectively). Overall, groundtanks had the best water quality and uncovered containers had the poorest water quality. Point-of-use water from groundtanks, open-top containers and closed-top containers all had heterotrophic organism and total coliform counts which exceeded the maximum allowed levels as per DWAF guidelines (indicated on Fig. 3 by broken lines) and hence posed a substantial risk of microbial infection to users (Fig. 3). The $95^{\text {th }}$ percentile (used here to indicate the upper limit of risk), for heterotrophic organisms and total coliforms, placed water from all three storage systems (groundtanks, open-top containers and closed-top containers) in the substantial risk category according to DWAF guidelines. Tanker-supplied water from open-top and closed-top containers also posed a substantial risk of microbial infection to users at the upper limit of risk $\left(95^{\text {th }}\right.$ percentile) for E. coli. Labelled boxes on the graph indicate significantly higher microbial counts at differing points-of-use.
Figure 4 shows the relationship between age distribution in households (households including children aged $0-5$ years, households including children aged between 5 and 18 years and households comprising adults only) and microbial quality of drinking water at the point-of-use. The highest heterotrophic organism and E. coli counts were observed in water from households including children aged $0-5$ years and which used open-top containers for water storage. Heterotrophic organism counts were significantly higher in this group in comparison to all closed-top container and groundtank-supplied household groups. Water in households comprising adults only and which used open-top containers for water storage displayed the highest total coliform counts, but not significantly so (Fig. 4). The upper risk limit ( $95^{\text {th }}$ percentile) indicates that heterotrophic organisms and total coliforms were present in large enough quantities in water from all three storage systems (groundtanks, open-top and closed-top containers) to pose substantial risk of microbial infection to users in terms of general water hygiene. For water in groundtank-supplied households, E. coli levels were very low and the upper limit of risk $\left(95^{\text {th }}\right.$ percentile) indicated that there was no risk of microbial infection to users from faecal contamination of water. Labelled boxes on the 

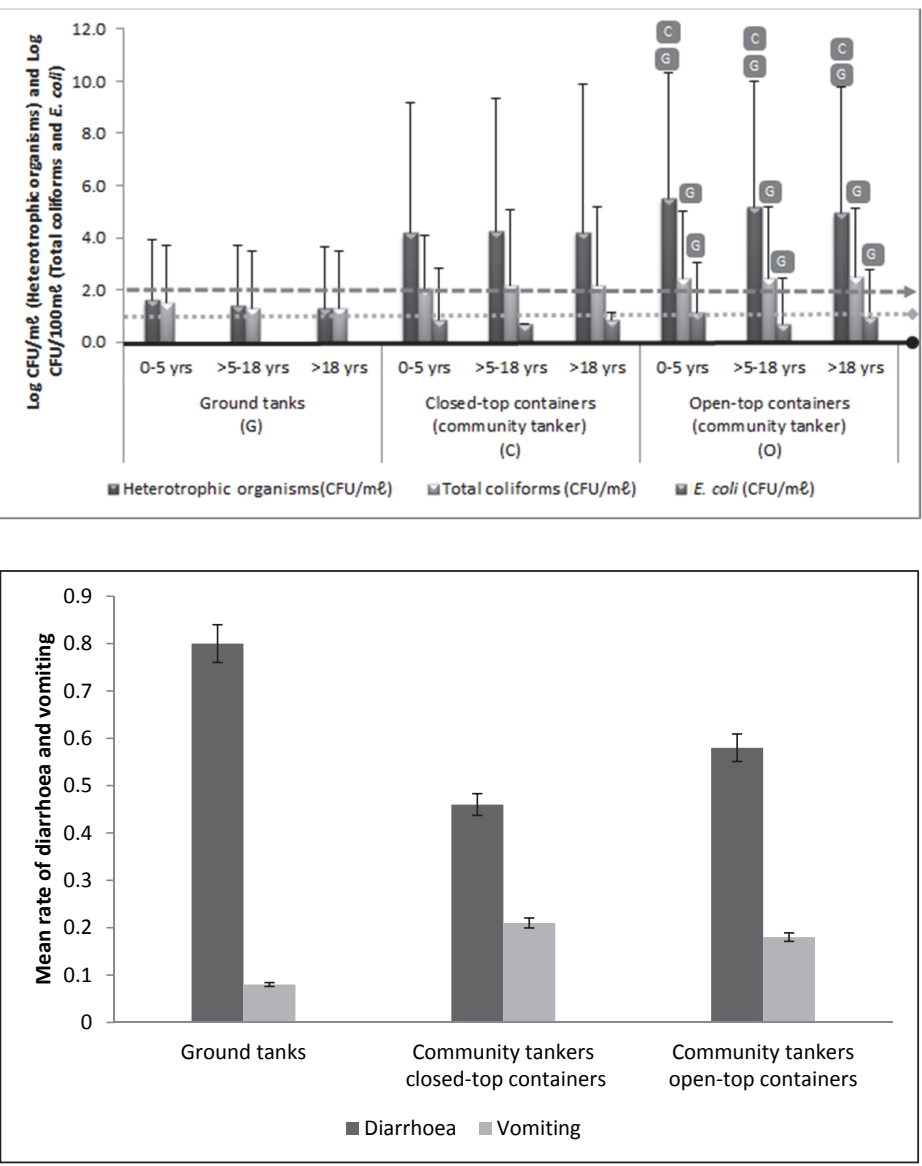

Figure 4

Arithmetic mean microbial counts for households including children aged $0-5$ years or children aged between 5 and 18 years, and households comprising adults only (>18 yrs), which use ground tanks, open-top or closed-top containers for domestic water storage and use. Error bars represents the $95^{\text {th }}$ percentile. Horizontal lines represent maximum values of heterotrophic organisms (dark grey line with arrowhead), total coliforms (grey line with diamond head) and $\mathrm{E}$. coli (black line with rounded head) counts allowed in drinking water rendered safe for human consumption by DWAF. Boxes represent significant differences in microbial counts.

\section{Figure 5}

Mean rates of diarrhoea and vomiting in households using groundtanks, open-top or closed-top containers for water storage and supply. Error bars represent the $95^{\text {th }}$ percentile. graph indicate where microbial counts are significantly higher than for other points-of-use.

Although groundtanks had the best water quality, they were not associated overall (irrespective of age of household members) with the lowest incidence of disease (Fig. 5). For example, households using groundtanks had a higher rate of diarrhoea when compared with households using open-top and closedtop containers. It should be noted that households in Sawpitts exclusively used groundtanks as a point of water use and that people in Sawpitts were less hygiene-conscious as indicated by fewer responses to hygiene questions $(p<0.0005)$, lower occurrence of hand-washing facilities and soap inside the homes ( $p<0.0005$ and $p=0.001$ respectively) and fewer responses that soap should be used when washing hands $(p=0.007)$.

Figure 6 shows the relationships among water quality at the point-of-use (storage containers and groundtanks), health outcomes (diarrhoea and vomiting) and age distribution in households. In general, the microbial quality of drinking water in households including children aged $0-5$ and between 5 and 18 years of age was worse than in households comprising adults only. Households using groundtanks and which had children in the 0-5 year range, had water with the lowest $E$. coli and total coliforms counts (Fig. 4). However, members of these households presented with the highest rate of vomiting, and this rate was significantly higher than in all other demographic groups receiving drinking water from groundtanks, open-top or closed-top containers $(p<0.001)$ (Fig. 6). Even though E. coli counts in groundtank water were lower than that in water from open-top or closed-top storage containers (Fig. 4), the highest rate of diarrhoea still occurred amongst members aged between
5 and 18 years in households using groundtanks for water storage. This rate was significantly higher than in all other demographic groups using groundtanks, open-top or closedtop storage containers as point-of-use water supplies $(p<0.001)$ (Fig. 6). On a qualitative basis, the rate of all health outcomes was significantly higher in households with children aged $0-5$ and between 5 and 18 years using open-top containers or groundtanks, respectively, as the point-of-use, in comparison to all other demographic groups using groundtanks, open-top or closed-top containers as a point-of-use water supply (Fig. 6).

\section{Relationship among socio-economic factors, microbial water quality and health}

Although Sawpitts households were provided with UD toilets, whilst those in Mtamuntengayo were not, not everyone in Sawpitts used these toilets. Some household members still preferred to practise open defecation. Table 3 shows that, for those households where not everyone used the UD toilet, there was a higher rate of diarrhoea $(p=0.036)$. Table 4 also shows that these households had a higher E. coli content in their drinking water at point-of-use. If the outside toilet was used but not cleaned regularly, significantly higher rates of diarrhoea were observed among toilet users $(p=0.028)$ (Table 3 ) and significantly higher E. coli counts were observed in drinking water (Table 4). This indicates that the use of UD toilets and practice of good hygiene were closely related to the aversion of cases of diarrhoea and to the maintenance of good quality drinking water.

Table 5 shows that there were higher levels of total coliforms and heterotrophic organisms in drinking water of those 


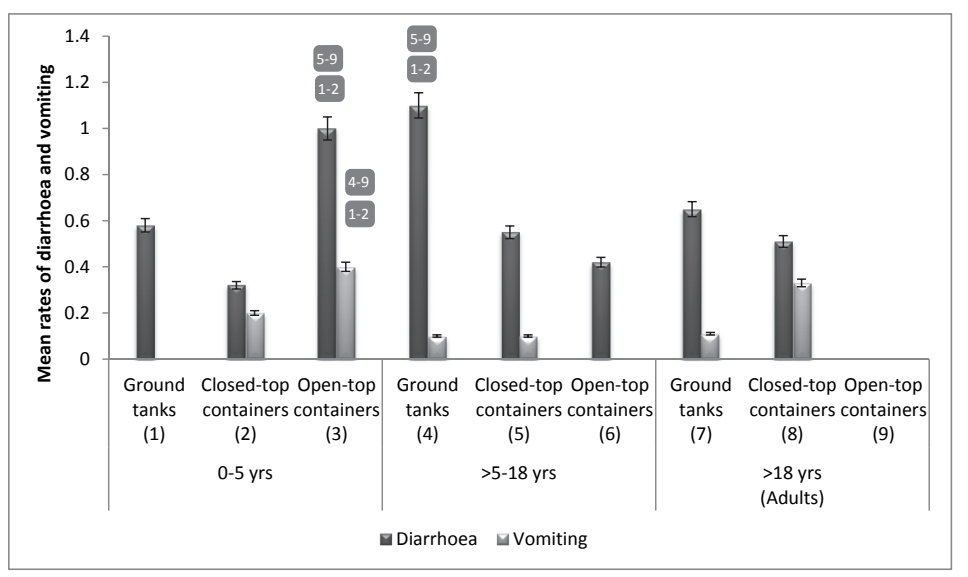

Figure 6

Mean rates of diarrhoea and vomiting in households using groundtanks, open-top or closed-top containers for domestic water storage at the pointof-use. Rate of diarrhoea and vomiting is also distinguished between by age distributions. Error bars represents the $95^{\text {th }}$ percentile. Labelled boxes represent significant differences in mean rates of diarrhoea and vomiting amongst the various age groups analysed; labels as shown on the horizontal axis.

TABLE 3

Sanitation, water quality/use and social factors associated with rate of diarrhoea. Asterisks indicate significance $(p<0.05)$

\begin{tabular}{|l|l|c|c|c|c|c|c|}
\hline Independent variables & \multicolumn{2}{|c|}{ Generalised linear modelling: Poisson distribution /log link function } & $\begin{array}{c}\text { Mann- } \\
\text { Whitney }\end{array}$ \\
\hline & $\begin{array}{l}\text { Category relative } \\
\text { to baseline }\end{array}$ & IRR & SE & \multicolumn{2}{c|}{ Confidence interval of IRR } & $p$ value & \\
\hline $\begin{array}{l}\text { Does everyone in the family use the } \\
\text { UD toilet? (baseline = yes) }\end{array}$ & No & 1.43 & 0.33 & 0.96 & 2.15 & 0.081 & $0.036^{*}$ \\
\hline $\begin{array}{l}\text { Is the outside toilet clean? (baseline } \\
=\text { yes) }\end{array}$ & No & 2.63 & 1.13 & 1.13 & 6.11 & $0.024^{*}$ & $0.028^{\star}$ \\
\hline
\end{tabular}

IRR: incidence rate ratio

SE: standard error

UD: urine diversion

TABLE 4

Association of sanitation and E. coli counts in drinking water $(p<0.05$ indicates a significantly higher count of E. coli associated with sanitation)

\begin{tabular}{|l|l|l|c|c|}
\hline $\begin{array}{l}\text { In variable based on household } \\
\text { and observational questionnaire }\end{array}$ & Result & $\begin{array}{c}\text { Statistical test } \\
\text { performed }\end{array}$ & $\begin{array}{c}\text { Level of } \\
\text { significance }\end{array}$ \\
\hline Do your children use UD toilets all the time? & No & Significantly higher E. coli counts & Mann-Whitney & $p=0.034$ \\
\hline Were UD toilet seats observed to be clean? & No & Significantly higher E. coli counts & Mann-Whitney & $p=0.035$ \\
\hline
\end{tabular}

TABLE 5

Association of sanitation, education indicators and poverty indicators with microbial counts in drinking water ( $p<0.05$ indicates a significantly higher microbial count associated with sanitation, education and poverty indicators)

\begin{tabular}{|c|c|c|c|}
\hline $\begin{array}{l}\text { Variable based on } \\
\text { observational and household questionnaires }\end{array}$ & Result & $\begin{array}{l}\text { Statistical test } \\
\text { performed }\end{array}$ & $\begin{array}{l}\text { Level of } \\
\text { significance }\end{array}$ \\
\hline $\begin{array}{l}\text { Open defecation practiced more than use of } \\
\text { UD toilets }\end{array}$ & $\begin{array}{l}\text { Significantly higher total } \\
\text { coliforms }\end{array}$ & Mann-Whitney & $p=0.034$ \\
\hline $\begin{array}{l}\text { Open defecation practiced more than use of } \\
\text { UD toilets }\end{array}$ & Significantly higher heterotrophic organisms & Mann-Whitney & $p=0.028$ \\
\hline $\begin{array}{l}\text { Presence of radios and refrigerators in } \\
\text { households }\end{array}$ & Significantly lower heterotrophic organisms & Mann-Whitney & $\begin{array}{l}p=0.037 \text { (fridge) } \\
p=0.046 \text { (radio) }\end{array}$ \\
\hline Absence of hand-washing facilities & Significantly higher total coliforms & Mann-Whitney & $p=0.0005$ \\
\hline
\end{tabular}

households where people practised open defecation as opposed to using outside toilets ( $p=0.034$ and $p=0.028$ ). It also shows that, where households had radios and refrigerators (measures of socio-economic status), heterotrophic organism counts in water at the point-of-use were significantly lower ( $p=0.046$ and $p=0.037$, respectively). The absence of hand-washing facilities was related to higher coliform counts in water $(p=0.0005)$.

Mtamuntengayo was compared with Sawpitts with regard to socio-economic factors and health (Table 6). Mann-Whitney tests showed that there were more households with books in Mtamuntengayo than in Sawpitts. Fischer's exact tests showed that (i) significantly fewer hand-washing facilities, (ii) significantly fewer responses to hygiene questions, and (iii) significantly fewer cases of soap provided were observed in households from Sawpitts than in households from Mtamuntengayo ( $p=0.0005, p=0.005$ and $p=0.001$, respectively). A significantly higher number of people in Mtamuntengayo said they used soap for hand-washing, compared to Sawpitts $(p=0.007)$. Together these results indicate that there was a lower standard of education and of hygiene in Sawpitts than in Mtamuntengayo (Table 6). No other significant differences were observed between age distributions and socio-economic factors. When place and age distributions were accounted for concurrently, cross tabulations showed that people in 
TABLE 6

Comparison of Sawpitts with Mtamuntengayo with regard to educational indicators, hygiene indicators and sanitation indicators

\begin{tabular}{|l|l|l|l|}
\hline Sawpitts & Mtamuntengayo & $\begin{array}{l}\text { Statistical test } \\
\text { performed }\end{array}$ & $\begin{array}{l}\text { Level of } \\
\text { significance }\end{array}$ \\
\hline & More books in Mtamuntengayo & Mann-Whitney & $p=0.033$ \\
\hline Fewer hand wash facilities & & Fischer's Exact & $p=0.0005$ \\
\hline Fewer responses to hygiene questions & & Fischer's Exact & $p=0.005$ \\
\hline Fewer observations of soap present & & Fischer's Exact & $p=0.001$ \\
\hline & More people wash hands with soap & Mann-Whitney & $p=0.007$ \\
\hline & More people practice open-defecation & Cross tabulation & \\
\hline
\end{tabular}

Mtamuntengayo practiced open defecation more often than people in Sawpitts (Table 6).

\section{DISCUSSION}

Of the two source waters that were considered, only the water dispensed directly from the municipal distribution system yielded water of acceptable quality (Table 2, Fig. 2). Poor microbial quality of tanker source water (Fig. 2) is likely to be due to biofilm presence, contamination of dispensing devices from tankers, contamination of water in the tanker by dust during transport and inefficient or inadequate water treatment. The hygiene of water tankers is of concern as communal tankers are seldom washed out. Water is also stored in the tanker for hours at a time, which allows for biofilm formation. It is well documented that microorganisms require a surface with nutrients and a flow of water to produce biofilm (Block et al., 1993; Camper, 1994; Costerton et al., 1994). Mean turbidity of water from tankers was above the recommended levels in WHO and DWAF guidelines (Table 2). High turbidity is typically associated with increased biofilm formation as a result of more particles being available to serve for attachment and nutritional purposes (Costerton et al., 1994).

Point-of-use water sampled from groundtanks showed that water quality deteriorated relative to the source in terms of heterotrophic organisms and total coliforms (Fig. 3). This could be a result of biofilm growth in the groundtank. Studies by Arjun and coworkers (2004) confirmed the presence of biofilm in groundtanks sampled from the Cato Manor region in Durban. In Sawpitts, water from groundtanks showed residual chlorine levels below WHO and DWAF recommended levels (Table 2), which meant that there was insufficient chlorine to protect against intruding micro-organisms. A possible source of this is leaf matter or soil which could be introduced because of loose lids, as was observed on occasion in groundtank-supplied communities.

Groundtank water was the only point-of-use water that had E. coli counts that indicated a negligible risk of infection to users from faecal contamination (Fig. 3). Despite this, members of groundtank-supplied households had the highest rates of diarrhoea, in comparison to tanker-supplied households (Fig. 5). This suggests that diarrhoea in this case was associated with factors other than drinking water. The low E. coli counts in groundtank drinking water could be explained by the presence of taps on groundtanks, even in cases where open defecation was practiced. Taps minimise the direct contact of drinking water with faecally-contaminated hands or dipping utensils. The lack of relationship between rates of diarrhoea and microbial quality of drinking water in groundtank-supplied households may also be a result of sampling techniques used, which were not typical of how water is used from these tanks. During sampling, groundtank taps were wiped with $90 \%$ ethanol and taps were flushed for $1 \mathrm{~min}$ before samples were collected, to ensure that water collected was not contaminated by the tap. This is not typical of water use practice by groundtank users.

Microbial contamination of drinking water stored in either open-topped or close-topped containers deteriorated relative to the tanker source (which in turn was itself of lower quality than water from the distribution system), in terms of heterotrophic organisms, total coliforms and E. coli (Fig. 3). The consumption of microbially-contaminated drinking water has been previously associated with increased rates of health outcomes such as diarrhoea and vomiting (Trevett et al., 2004; Clasen et al., 2005; Yang et al., 2011). The present study showed that increased incidence of vomiting was probably linked to high E. coli counts in water from open-top storage containers.

Drinking water at point-of-use in households using opentop storage containers had the highest faecal contamination of water, in terms of $E$. coli, compared to drinking water in households using closed-top storage containers and groundtanks (Fig. 3). Drinking water at point-of-use from households using open-top storage containers and including children aged $0-5$ years had higher heterotrophic organisms, total coliforms and $E$. coli counts than that in households including children aged between 5 and 18 years and households comprising adults only ( $>18$ years) (Fig. 4). These households also presented with the highest rates of diarrhoea and vomiting (Fig. 5). Here a link between microbial quality of drinking water, age distribution in households and rates of health outcomes is clearly shown.

The deterioration in microbial quality of drinking water from source to point-of-use and its relation to hygiene practices has been demonstrated in numerous studies (Islam et al., 2001; Trevett et al., 2005; Peter, 2010). Lack of proper hygiene practices, such as cleaning of drinking water storage vessels and dipping utensils used to remove drinking water from storage vessels, and washing of hands, as well as exposure of drinking water stored in open-top containers to dust and fomites has been shown to contribute to decreased microbial quality of drinking water, in this study as well as in the literature (Blum et al., 1990; Tuttle et al., 1995; Trevett et al., 2005; Onabulo et al., 2011).

Contamination routes of drinking water stored in opentop containers by children have been demonstrated. Using improved drinking water storage containers - defined as containers which minimise hand-contact with drinking water and which offer protection from microbial contamination of drinking water through the presence of lids - results in a significant decrease in microbial contamination of drinking water, especially in children less than 5 years of age (Empereur-Bissonnet et al., 1992; Roberts et al., 2001). A significant association 
between incidences of diarrhoeal disease in children younger than 5 years of age and the type of drinking water storage container used has also been reported (Yeager et al., 1991; Mahmud et al., 2001).

Provision of groundtanks, UD toilets (which incorporate a hand-washing area in the design of the unit to promote handwashing after toilet use) and hygiene education as a package, as practised by eThekwini Municipality, was aimed at promoting proper and safe sanitation practices, hand washing and supply of microbially-safe drinking water for users at the point-ofuse. It was surprising to find in this study that, even though people were provided with sanitation utilities and the education regarding use thereof as a package, some households still practised open defecation (Table 2). Urine diversion toilets were not consistently kept clean and hand-washing amongst members from groundtank-supplied households was lower than in members from households supplied by tankers (Tables $2-5$ ). This discrepancy between hygiene education and hygiene practices warrants further investigation.

In this study it was demonstrated that households which practiced open defecation had the highest levels of E. coli in drinking water at the point-of-use and the highest rates of diarrhoea and vomiting. Conversely, households that used UD toilets and kept them clean were associated with decreased microbial contamination of drinking water and decreased rates of health outcomes. There is ample evidence that defecation practices (open defecation vs. UD toilets or pit latrines) contributes to poor microbial quality of drinking water and increase in health outcomes such as diarrhoea (VanDerslice and Briscoe, 1995; Root, 2001; Trevett et al., 2005; Trevett and Carter, 2008; Hubbard et al., 2011). It has also been shown that when open defecation is practised, people are less likely to wash their hands (Trevett et al., 2004; Isunju et al., 2011). Even if they do, washing of hands would require the removal of water from storage vessels using dipping utensils or the touching of taps on delivery systems such as groundtanks. This demonstrates a route for transfer of faecal contaminants from contaminated hands to point-of-use drinking water (Quick et al., 1999). Furthermore, when open defecation is practised, the overall sanitary quality of the environment deteriorates (Trevett et al., 2005). This can result in exposure to faecal matter from more than one household, which means exposure to a variety of external pathogens with which members of a given single household would not necessarily have contact. This in turn increases the risk of contracting faecal-oral diseases since members of a given household would be less likely to be immune to pathogens from members of other households defaecating in the same vicinity (Faechem et al., 1983; VanDerSlice and Briscoe, 1995; Isunju et al., 2011).

Households using open-top containers for storage of drinking water also practised open defecation more commonly. Hand-washing with soap was more prevalent in households using open-top and closed-top containers for drinking water storage than in households using groundtanks. Tankersupplied households had higher rates of vomiting than did groundtank-supplied households, despite better hand-washing practices. This could be attributed to the process of hand-washing. In the case of households using containers devoid of a tap (as in community-tanker-supplied households), water needed for washing of hands would be removed from storage vessels either by using a dipping utensil or by pouring out water. Contact of faecally-contaminated hands with dipping utensils or water could result in faecal contamination of drinking water which could then result in increased rates of associated health outcomes. An earlier study demonstrated a similar occurrence, in which refugees using containers for water storage reported that they either inserted their hands into water storage containers to remove water for washing hands or that they rinsed their hands directly in the container containing water used for drinking purposes (Swerdlow et al., 1997).

The current study also investigated the impact of socio-economic status of household members on the microbial quality of drinking water and rates of health outcomes (diarrhoea and vomiting). It was demonstrated that households with a higher poverty index (measured by income per household, with a household having a high poverty index being in a lower income bracket than households with low poverty index) and lower education level (measured by presence of books, newspapers or educational material) had higher heterotrophic organisms, total coliforms and E. coli counts in their point-of-use drinking water than households with lower poverty index and higher education levels. Households of high poverty index and low socio-economic status also had the highest rates of diarrhoea and vomiting. Other authors have similarly demonstrated that poor socio-economic status is associated with poorer hygiene and with increased rates of poor health outcomes (Ettner, 1996; Feinstein, 1999; Sohel Rana, 2009; Isunju et al., 2011). The impact of education and income on health outcomes has also been demonstrated (Manun'Ebo et al., 1994; Mahmud et al., 2001; Trevett et al., 2005; Jalan and Samathan, 2008). These studies showed that the duration for which diarrhoea lasts in children in low-income households was significantly longer than in higher-income households. It was found that a decrease in parental education was related to increased rates of diarrhoea amongst children aged 0-3 years (Manan'Ebo et al., 1994) while increased education increased the likelihood of interventions to improve water quality (Jalan and Samathan, 2008). Illiteracy was associated with increased rates of persistent diarrhoea (Mahmud et al., 2001). It was also demonstrated that making use of knowledge of good hygiene practice is to some extent dependent upon household income (Trevett, 2003; Trevett et al., 2005; Sohel Rana, 2009), suggesting that poor households had limited ability to improve or maintain sanitary environments.

Overall this study demonstrated relationships between deterioration of microbial drinking water quality, type of sanitation practices, hygiene practices, socio-economic factors and rates of health outcomes (diarrhoea and vomiting). This is in accordance with studies by several investigators, which have demonstrated that the reduction in health outcomes in lowincome areas cannot be reduced only by providing safe drinking water at the point-of-use, but rather that improved health outcomes can be achieved most successfully by providing proper sanitation, safe drinking water at the source and pointof-use, and hygiene education, all implemented collectively (Feachem et al., 1983; Esrey et al., 1991; Curtis et al., 2000; Trevett et al., 2005; Sohel Rana, 2009; Peter, 2010).

\section{RECOMMENDATIONS}

Communal water tankers should be thoroughly cleaned on a regular basis. Addition of disinfectant to water in tankers could be considered. Tanker operators should be educated in basic water hygiene.

To improve the health outcomes of users of groundtanks, users should be made aware of the importance of keeping tanks closed, of washing hands before handling the tap, and of cleaning groundtanks regularly. 
Reasons for continued open defecation and poor hygiene practices despite the provision of piped water via groundtanks, a UD toilet and hygiene education should be investigated and addressed.

\section{ACKNOWLEDGEMENTS}

This study was supported by eThekwini Municipality and by the South African National Research Foundation. eThekwini Municipality is further thanked for logistical support. Professor Thor-Axel Stenström and the Swedish Institute of Infectious Disease Control are thanked for guidance and support in the epidemiological study on which the present study is based.

\section{REFERENCES}

AMERICAN SOCIETY FOR MICROBIOLOGY (2000) Water-related health illness. URL: http://www.microbeworld.org/html/cissues/ water/wqual $1 \mathrm{htm}$ (Accessed May 2008).

ARJUN N, JOUBERT JP, RODDA N, SMITH M and BUCKLEY C (2004) Water quality at point-of-use for users supplied by standpipes and groundtanks in a peri-urban community. IWA Specialist Group Conference on Water and Wastewater Management for Developing Countries, 28-30 July 2004, Victoria Falls, Zimbabwe.

BAQUI AH, BLACK RE, YUNUS M, HOQUE AR, CHOWDHURY HR and SACK RB (1991) Methodological issues in diarrhoeal diseases epidemiology: definition of diarrhoeal episodes. Int. J. Epidemiol. 20 1057-1063.

BLOCK JC, HAUDIDIER K, PAQUIN JL, MIAZGA J and LEVI Y (1993) Biofilm accumulation in drinking water distribution systems. Biofouling 6 333-343.

BLUM D, EMEH RN, HUTTLY SRA, DOSUNMU-OGUNBI O, OKEKE N, AJALA M, OKORO JI, AKUJOBI C, KIRKWOOD BR and FEACHEM RG (1990) The Imo State (Nigeria) drinking water supply and sanitation project, 1 . Description of the project, evaluation methods, and impact on intervening variables. Trop. Med. Hyg. 84 309-315.

CAMPER AK (1994) Coliform regrowth and biofilm accumulation in drinking water systems: a review. In: Geesey GG, Lewandowski Z and Flemming HC (eds.) Biofouling and Biocorrosion in Industrial Water Systems. Lewis Publishers, Boca Raton. 91-105.

CHANLETT ET (1992) Environmental Protection. McGraw-Hill Book Company, New York

CLASEN T, ROBERTS I, RABIE T, SCHMIDT W-P and CAIRNCROSS S (2006) Interventions to improve water quality for preventing diarrhoea. In: The Cochrane Library, Issue 3, 2006. Update Software, Oxford.

COSTERTON JW, LEWANDOWSKI Z, DE BEER D, CALDWELL D, KORBER D and JAMES G (1994) Biofilms, the customised microniche. J. Bact. 176 2137-2142.

CURTIS V, CAIRNCROSS S and YONLI R (2000) Domestic hygiene and diarrhoea: pinpointing the problem. Trop. Med. Int. Health $\mathbf{5}$ (1) 22-32.

DWAF (DEPARTMENT OF WATER AFFAIRS AND FORESTRY SOUTH AFRICA) (2002) Free basic water: tap into life, regulations and guidelines, guidelines for compulsory national standards and norms and standards for water services tariffs and water services provider contract regulations. Department of Water Affairs and Forestry, Pretoria.

EMPEREUR-BISSONNET P, SALZMAN V and MONJOUR L (1992) Application d'un nouveau mate' riel de transport et de stockage pour l'ame' lioration de la qualite' de l'eau de boisson en milieu rural africain. Bull. Social Path. 85 390-394.

ETHEKWINI MUNICIPALITY (2004a) Test Method MM002 2004. Analysis of Total Coliforms and E. coli on Chromocult Medium using the Membrane Filter Procedure. Scientific Services, eThekwini Water and Sanitation, Durban.

ETHEKWINI MUNICIPALITY (2004b) Test Method MM007 2004 Heterotrophic Plate Count. Scientific Services, eThekwini Water and Sanitation, Durban.
ESREY SA, POTASH JB, ROBERTS L and SHIFFMAN C (1991) Effects of improved water supply and sanitation on ascariasis, diarrhoea, dracunculiasis, hookworm infection, schistosomiasis, and trachoma. Bull. World Health Organ. 69 609-621.

ETTNER SL (1996) New evidence on the relationship between income and health. J. Health Econ. 15 67-85.

FEACHEM SA, BRADLEY DJ, GARELICK H and MARA DD (1983) Sanitation and Disease: Health Aspects of Excreta and Wastewater Management. World Bank Studies in Water Supply and Sanitation. John Wiley and Sons, New York.

FEINSTEIN JS (1999) The relationship between socio-economic status and health: A review of the literature. The Millbank Q. 71 (2) 279-322.

GUNDRY SW, WRIGHT JA, CONROY R, DU PREEZ M, GENTHE B, MOYO S, NDAMBA J and POTGIETER N (2006) Contamination of drinking water between source and point-of-use in rural households of South Africa and Zimbabwe: implications for monitoring the Millennium Development Goal for Water. Water Pract. Technol. 1 (2) 1-9.

GUYTON AC and HALL JE (2006) Textbook of Medical Physiology ( $11^{\text {th }}$ edn.). Saunders, Philadelphia. 439-441.

HUBBARD B, SARISKY J, GELTING R, BAFFIGO V, SEMINARIO $\mathrm{R}$ and CENTURION C (2011) A community demand-driven approach toward sustainable water and sanitation infrastructure development. Int. J. Hyg. Environ. Hyg. 214 326-334.

ISLAM MS, HOSSAIN MA, KHAN SI, KHAN MNH, SACK RB, ALBERT MJ, HUQ A and COLWELL RR (2001) Survival of Shigella dysenteriae Type 1 on fomites. J. Health Popul. Nutr. 19 (3) $177-182$.

ISUNJU JB, SCHWARTZ K, SCHOUTEN MA, JOHNSON WP and VAN DIJK MP (2011) Socio-economic aspects of improved sanitation in slums: A review. Public Health 125 368-376.

JAGALS P, GRABOW WOK and WILLIAMS E (1997) The effects of supplied water quality on human health in an urban development with limited basic subsistence facilities. Water SA 23 (4) 372-379.

JAGALS P, NALA NP, TSUBANE TJ, MOABI M and MOTAUNG KC (2004) Measuring changes in water-related and hygiene practices by developing community households. Water Sci. Technol. 50 (1) 91-97.

JALAN J and SOMANATHAN E (2008) The importance of being informed: Experimental evidence on demand for environmental quality. J. Dev. Econ. 87 14-28.

KWAZULU-NATAL MUNICIPALITIES (2008) Drinking water supply in Durban, Methods of Delivery. URL: www.kznmunicipalities. co.za (Accessed 13 April 2008).

LUTCHMINARAYAN R (2007) A Comparative Study Evaluating the Health Impacts of Ecological Sanitation Interventions, Water Services and Hygiene Education Programmes Individually and in Combinations, in eThekwini District, Durban, South Africa. MSc thesis, University of KwaZulu-Natal, Durban, South Africa.

MAHMUD MA, HOSSAIN MM, HUANG DB, HABIB M and DUPONT HL (2001) Socio-demographic, environmental and clinical risk factors for developing persistent diarrhoea among infants in a rural community of Egypt. J. Health Popul. Nutr. 19 (4) 313-319.

MANUN'EBO MN, HAGGERTY PA, KALENGAIE M, ASHWORTH $A$ and KIRKWOOD BR (1994) Influence of demographic, socioeconomic and environmental variables on childhood diarrhoea in a rural area of Zaire. J. Trop. Med. Hyg. 97 31-38.

MOMBA MNB and NOTSHE TL (2003) The microbiological quality of groundwater derived drinking water after long storage in household containers in a rural community of South Africa. J. Water Supply: Res. Technol. AQUA 52 (1) 66-67.

MOYO S, WRIGHT J, NDAMBA J and GUNDRY S (2004) Realising the maximum health benefits from water quality improvements in the home: a case from Zaka district, Zimbabwe. Phys. Chem. Earth 29 1295-1299.

ONABULO B, JIMOH OD, IGBORO SB, SRIDHAR MKC, ONYILO G, GEGE A and ILYA R (2011) Source to point of use drinking water changes and knowledge, attitude and practices in Katsina State, Northern Nigeria. Phys. Chem. Earth 36 1189-1196. 
PAYMENT P, FRANCO E and SIEMIATYCKI J (1993) Absence of relationship between health effects due to tap water consumption and drinking water quality parameters. J. Water Sci. Technol. 27 (3) 137-143.

PAYMENT P, RICHARDSON L, SIEMIATYCHI J, DEWAR R, EDWARDS M and FRANCO E (1991) A randomized trial to evaluate the risk of gastrointestinal disease due to the consumption of drinking water meeting current microbiological standards. Am. J. Public Health 81 703-708.

PETER G (2010) Impact of rural water projects on hygienic behaviour in Swaziland. Phys. Chem. Earth 35 772-779.

QUICK RE, VENCZEL LV, MINTZ ED, SOLETO L, APARICIO J, GIRONAZ M, HUTWAGNER L, GREENE K, BOPP C, MALONEY K, CHAVEZ D, SOBSEY M and TAUXE RV (1999) Diarrhoea prevention in Bolivia through point-of-use water treatment and safe storage: a promising new strategy. Epidemiol. Infect. 122 83-90.

ROBERTS L, CHARTIER O, MALENGA G, TOOLE M and RODKA $\mathrm{H}$ (2001) Keeping clean water in a Malawi refugee camp: a randomized intervention trial. Bull. World Health Organ. 79 280-287.

ROOT GPM (2001) Sanitation, community environments, and childhood diarrhoea in rural Zimbabwe. J. Health Popul. Nutr. 19 (2) 73-82.

SOHEL RANA MD (2009) Status of water use, sanitation and hygienic condition of urban slums: A study of Rupsha Ferighat slum, Khulna. Desalination 246 322-328.

STANDARD METHODS (2005) Standard Methods for the Examination of Water and Wastewater. American Public Health Association, American Water Works Association and Water Environment Federation, USA.

SWERDLOW DL, MALENGA G, BEGKOYIAN G, NYANGULU D, TOOLE M, WALDMAN RJ, PUHR DND and TAUXE RV (1997)
Epidemic cholera among refugees in Malawi, Africa: treatment and transmission. Epidemiol. Infect. 118 207-214.

TREVETT AF (2003) The Public Health Significance of Drinking Water Quality Deterioration in Rural Honduran Communities. PhD thesis, Cranfield University, UK.

TREVETT AF and CARTER R (2008) Targeting appropriate interventions to minimise deterioration of drinking-water quality in developing countries. J. Health Popul. Nutr. 26 (2) 125-138.

TREVETT AF, CARTER RC and TYRREL SF (2004) Water quality deterioration: a study of household drinking-water quality in rural Honduras. Int. J. Environ. Health 14 273-283.

TREVETT AF, CARTER RC and TYRREL SF (2005) The importance of domestic water quality management in the context of faecal-oral disease transmission. J. Water and Health 3 (3) 221-228.

TUTTLE J, RIES AA, CHIMBA RM, PERERA CU, BEAN NH and GRIFFIN PM (1995) Antimicrobial resistant epidemic Shigella dysenteriae Type 1 in Zambia: modes of transmission. J. Infect. Dis. $171371-375$.

VANDERSLICE J and BRISCOE J (1995) Environmental interventions in developing countries: Interactions and their implications. Am. J. Epidemiol. 141 (2) 135-144.

WHO (WORLD HEALTH ORGANIZATION) (2005) Guidelines for Drinking Water Quality, Recommendations. Vol. 1 ( $3^{\text {rd }}$ edn.). World Health Organization, Geneva.

YANG Z, WU X, LI T, LI M, ZHONG Y, LIU Y, DENG Z, DI B, HUANG C, LIANG H and WANG M (2011) Epidemiological survey and analysis on an outbreak of gastroenteristis due to water contamination. Biomed. Environ. Sci. 24 (3) 275-283.

YEAGER BA, LANATA CF, LAZO F, VERASTEGUI H and BLACK RE (1991) Transmission factors and socio-economic status as determinants of diarrhoeal incidence in Lima, Peru. J. Diarrhoeal Dis. 9 186-193. 
http://dx.doi.org/10.4314/wsa.v39i5.11 Available on website http://www.wrc.org.za

ISSN 0378-4738 (Print) = Water SA Vol. 39 No. 5 October 2013 ISSN 1816-7950 (On-line) = Water SA Vol. 39 No. 5 October 2013 